\title{
Role of Nitrogen Fertilizer on Cadmium Uptake by Ramie (Boehmeria nivea (L.) Gaudich) Grown on Cadmium Contaminated Soil
}

\author{
Reginawanti Hindersah, Anne Nurbaity \\ Faculty of Agriculture Padjadjaran University \\ Jalan Raya Bandung-Sumedang Km. 21, Jatinangor \\ 45363 Indonesia \\ *Corresponding author: Tel/Fax 62-22-7796316; \\ reginawanti@unpad.ac.id
}

\author{
Dedi Nursyamsi \\ Agricultural Environment Research Institute \\ Jalan Raya Jakenan-Jaken Km 05, PO Box 05, \\ Jakenan, Pati 59162 Indonesia
}

\begin{abstract}
Continues phosphate fertilization as well as organic matter amendment can increase cadmium concentration in soil and induce more cadmium uptake by plants. Pytoremediation using non edible plant such as ramie (Boehmeria nivea L. Goud) is cheap and effective method to extract Cd from Cd-contaminated soil. Since in plant tissue $\mathrm{Cd}$ is bound in phytochelatin peptide which contains nitrogen and sulphur, the objective of this green house experiment was to assess the influence of nitrogen fertilizer in form of urea on cadmium uptake, nitrogen and sulphur concentration in shoots as well as shoot dry weight of 60-day old ramie grown in cadmium-contaminated soil. The experiment was set up in a Split Plot Design with two treatments and three replications. The main plot was cadmium levels $\left(0,10\right.$ and $\left.15 \mathrm{mg} \mathrm{kg}^{-1}\right)$ and subplot was urea level $\left(0,5.0\right.$ and $\left.7.5 \mathrm{~g} \mathrm{pot}^{-1}\right)$. The result showed that the increase of cadmium concentration in soil enhanced its concentration in ramie shoot regardless of urea levels. However either cadmium or urea did not change sulphur concentration in ramie shoot. Urea of 7,5 g/pot increased shoot dry weight but adding $\mathrm{CdCl}_{2} . \mathrm{H}_{2} \mathrm{O}$ of $15 \mathrm{mg} / \mathrm{kg}$ did not change shoot dry weight. This experiment demonstrated that ramie was able to grow in relatively high level of soil cadmium, and higher cadmium uptake by ramie shoot was not followed by an increase in nitrogen as well as sulphur uptake.
\end{abstract}

Keywords: Cadmium, Urea, Nitrogen, Sulphur, Ramie.

\section{INTRODUCTION}

Naturally, soil contains heavy metal Cadmium $(\mathrm{Cd})$ in various concentrations which depend on parent material, soil genesis and heavy metal translocation in soil (Alloway, 1995a). However certain anthropogenic activities increased $\mathrm{Cd}$ concentration in soil. Cadmium contamination in agricultural soil might be derived from phosphate fertilizer, manure and sludge (Alloway, 1995b; Chien et al., 2003). Cadmium is a non essential metal in higher plant metabolism. However, when $\mathrm{Cd}$ is available in soil, plants roots absorb $\mathrm{Cd}$ and distribute it to aerial parts. Since $\mathrm{Cd}$ in soil solution was more mobile than $\mathrm{Cr}, \mathrm{Pb}$, and $\mathrm{Cu}$ (Gomes et al., 2001), biological availability of $\mathrm{Cd}$ for plant was higher than that of other heavy metals. Increasing $\mathrm{Cd}$ concentration in agricultural soil adversely affecs the quality of soil and could threat food chain.
Phytoremediation is recommended technology for reclamation of heavy metalcontaminated soil due to its simplicity, relatively low cost and in situ approach (Choundhry et al., 1998). Accumulator plants should be non edible plants that survive from high concentration of contaminates in their aerial tissue (Choudhry et al., 1998). Over the past years, some researchers in Indonesia recommend the use of ramie (Boehmeria nivea (L.) Gaudich) as metal accumulator. Fibers of ramie are one of the best natural fibers and are used as textile fibers elsewhere.

Cadmium is a strong phytotoxic heavy metal for microbe, plant and animal. The main symptoms of $\mathrm{Cd}^{2+}$ toxicity to crop plants are stunting and chlorosis (Alloway, 1995b). Plants develop tolerancy to Cd toxicity by synthesizing cystein-rich phytochelatins (PC) peptide which binds $\mathrm{Cd}$ prior to enter vacuoles and plastids 
(Eapen \& D'Souza, 2005) where PC-CdS complexes are formed (Cobbett, 2000). Since in plant tissue $\mathrm{Cd}$ is bound in phytochelatin peptide which contains nitrogen and sulphur, plants grown in Cd contaminated soil might affect either $\mathrm{N}$ or S uptake to facilitate PC-CdS formation in vacuole. Type and quantity of $\mathrm{PC}$ changed in lettuce shoots due to change of Cd concentration (Hindersah et al, 2008). In order to better understand the effects of heavy metals on the growth and metabolisms of phytoaccumulator plants, pot experiment was performed to study $\mathrm{N}$ and $\mathrm{S}$ uptake by shoot of ramie following some level of Cd and urea treatments.

\section{MATERIALS AND METHODS}

Pot experiment was conducted in green house at Seed Inspection and Certification Institute of Food and Horticultural Plants in Bandung, West Java Province, Indonesia during November 2010 to January 2011. Transplant of local variety of ramie was prepared by Agricultural Environment Research Institute in Pati, Central Java Province. Single ramie's transplants were grown in $2.5 \mathrm{~L}$ polybag containing mixture of $2 \mathrm{~kg}$ of $\mathrm{Cd}$-uncontaminated transplant. Control plants received the same volume of aquadest instead of $\mathrm{Cd}$ and urea dilution. At the day of planting, $100 \mathrm{~mL}$ of liquid culture of Cd-resistent N-fixing bacteria Azotobacter sp. containing $10^{7} \mathrm{cfu} \quad \mathrm{mL}^{-1}$ was inoculated to the soil around cutting stem.

During experiment, plants received no other inorganic fertilizer except urea, and were watered by tap water once a day. Hand weeding was done every week when it was necessary. Pesticide was not applied since no pest infestation was noticed. All plants were maintained in green house for 2 months.

At the harvest time, plants were cut off at ground level, sample of shoot, roots and soil were collected and examined from each pot. Shoots and roots were collected separately and dried at $65^{\circ} \mathrm{C}$ for two consecutive days to obtain constant weight after placing them in desiccators for 20 minutes. Cadmium, $\mathrm{N}$ and $\mathrm{S}$ concentration in shoot were also measured. Soil was mixed thoroughly and $50 \mathrm{~g}$ of soil sample was collected for Cd analysis.

Cadmium concentration in shoots extract was determined with Atomic Absorption Spectroscopy (AAS) after total digestion with soil and $100 \mathrm{~g}$ of compost. The soil was top soil of Inceptisols (sand $17.5 \%$, loam $43.9 \%$, clay $38.6 \%$, $\mathrm{pH} \mathrm{H}_{2} \mathrm{O}$ 6.56, organic-C $1.64 \%$; total-N $0.28 \%$,

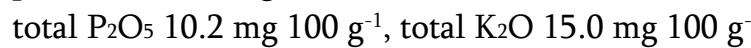
${ }^{1}$, cation exchange capacity $15.85 \mathrm{cmol} \mathrm{kg}^{-1}$, base saturation $48.6 \%$ ) taken from Jatinangor in Sumedang District West Java. Compost was a commercial compost made from manure and domestic organic waste $\left(\mathrm{pH} \mathrm{H}_{2} \mathrm{O} 7.31\right.$, organic-C $21.46 \%$, total-N 0.95\%, C/N 23, $\mathrm{P}_{2} \mathrm{O}_{5} 0.40 \%, \mathrm{~K}_{2} \mathrm{O}$ $0.38 \%$, Cd $0.014 \mathrm{mg} \mathrm{kg}^{-1}$, cation exchange capacity $22,32 \mathrm{cmol} \mathrm{kg}^{-1}$ ).

\section{Experimental Set Up}

A factorial randomized block experimental design with two Cd levels $\left(\mathrm{CdCl}_{2} \cdot \mathrm{H}_{2} \mathrm{O}\right.$ of 10 and $\left.15 \mathrm{mg} \mathrm{kg}^{-1}\right)$ at two different urea levels (5 and $7.5 \mathrm{~g}$ per polybag) and with three replicates was performed in green house. $\mathrm{CdCl}_{2} . \mathrm{H}_{2} \mathrm{O}$ was diluted in non autoclaved aquadest and was mixed thoroughly with soil in polybag three days before planting. Fourteen-day old ramie transplants having three buds were grown in growth media. Diluted urea was applied three days (1/2 dose) and one month (1/2 dose) after transplanting by pouring it on the soil around the

strong acids (nitric p.a. and perchloric acid p.a.) explained by Bradl et al. (2005). Available Cd in soil was determined with AAS after $\mathrm{CaCl}_{2} 0.01 \mathrm{M}$ extraction. Shoots (fresh and dry) were weighed and analyzed for total $\mathrm{N}$ by Kjeldahl procedure using catalyst mixture of $\mathrm{K} 2 \mathrm{SO} 4$ - $\mathrm{CuSO} 4.5 \mathrm{H} 2 \mathrm{O}-$ Se (Jones, 2001). Shoot samples were analyzed for total S by using AAS after wet combustion with concentrate of $\mathrm{HNO}_{3}$ and $\mathrm{HClO}_{4}$ p.a. (Jones, 2001).

\section{Statistical analysis}

Data were analysed with two factors analysis of variance (5\% F test) and followed by $5 \%$ Duncan's Multiple Range Test if there was significance effect of treatments on variables measured.

\section{RESULTS AND DISCUSSION}

\section{Shoot Dry Weight}

Based on statistical analysis, there was no significant interaction effect between $\mathrm{Cd}$ and urea on shoot dry weight of 60 day old ramie. Only urea showed positive effect on dry weight of ramie's shoots (Table 1.) since nitrogen is an essential macronutrient for plant metabolisms. 
Table 1. Effect of Cd and urea addition on shoot dry weight of 60 day-old ramie

\begin{tabular}{ccccc}
\hline \multirow{2}{\mathrm{CdCl}_{2}\mathrm{H}_{2}\mathrm{O}}{$\left(\mathrm{mg} \mathrm{kg}^{-1}\right)$} & \multicolumn{4}{c}{ Urea (g per pot $)$} \\
\cline { 2 - 4 } & Control & 5.0 & 7.5 & Average \\
\hline Control & 2.64 & 3.54 & 3.01 & $3.06 \mathrm{a}$ \\
10 & 3.12 & 4.03 & 3.20 & $3.45 \mathrm{a}$ \\
15 & 2.52 & 3.47 & 2.95 & $2.98 \mathrm{a}$ \\
Average & $2.76 \mathrm{a}$ & $3.68 \mathrm{~b}$ & $3.05 \mathrm{a}$ \\
\hline
\end{tabular}

No change in shoot weight in soil with Cd. This suggested that ramie could be well adapted to Cd concentration up to $15 \mathrm{mg} \mathrm{kg}^{-1}$ in soil. Shoot dry weight of plants grown in each level of Cd was similar without any Cd toxicity symptoms. This proved that ramie might be quite resistant to relatively high $\mathrm{Cd}$ concentration in soil. However, reduced growth of crop plant grown in high $\mathrm{Cd}$ concentration was reported elsewhere. After 1 week of Cd treatment, a sharp decline in biomass accumulation in the leaves and roots of tomato (Lycopersicon esculentum) was observed (Chaffei et al., 2004). Soil Cd at 100 and $150 \mathrm{mg} \mathrm{kg}^{-1}$ clearly decreased length, fresh and dry weights of shoot and root systems of Radish (Raphanus sativus L. var. sativus) as well as leaf number per plant (Farouk et al., 2011).

Some experiment demonstrated that a relatively high level of Cd in soil did not change plant growth. Hindersah et al. (2007) showed that $10 \mathrm{mg} / \mathrm{kg} \mathrm{CdCl} 2$ did not influence fresh weight of lettuce (Lactuca sativa L.), though according to Mengel and Kirkby (1987) soil contain $4 \mathrm{mg} \mathrm{kg}^{-1}$ is classified as Cd-contaminated soil. Izadiyar and Yargholi (2010) reported that there was no toxicity symptoms in alfalfa (Medicago sativa), shorgum (Shorgum spp.), clover (Trifolium spp.) and sainfoin (Onobrychis vicifolia) grown in pot containing 50 and $100 \mathrm{mg} \mathrm{kg} \mathrm{kg}^{-1} \mathrm{Cd}$. Some experiments showed Cd toxicity depends on plant species and soil characteristics (Alloway, 1995b).
In our research, ramie had normal growth with 15 mg kg-1 $\mathrm{CdCl}_{2} \cdot \mathrm{H}_{2} \mathrm{O}$ amendment which justify the ability of ramie to avoid toxic effect when it was grown in Cd-contaminated soil. At $15 \mathrm{mg} \mathrm{kg}^{-1}$ $\mathrm{CdCl}_{2} \mathrm{H}_{2} \mathrm{O}$ amendment might not be high enough to cause $\mathrm{Cd}$ toxicity in ramie. An experiment testing $\mathrm{Cd}$ higher than $15 \mathrm{mg} \mathrm{kg}^{-1}$ should be performed.

\section{Cadmium Concentration of Shoot}

Interaction effect of cadmium and urea on Cd concentration in shoot of ramie was significant. Cadmium concentration in shoots of ramie grown in $\mathrm{Cd}$ amended soil was only slightly higher than control (Table 2). Acidity of Inceptisols used in this experiment was 6.56 ( $\mathrm{pH} 2 \mathrm{o}$ ). The $\mathrm{pH}$ that tends to be neutral may cause immobilization of Cd in soil (Alloway, 1995b). This could be the reason why in this pot experiment in which ramie was grown in $\mathrm{Cd}$ contamined soil did not accumulate higher level of $\mathrm{Cd}$ in their aerial part. Our previous study demonstrated that ramie grown in neutral soil without any fertilizer could accumulate up to 40 $\mathrm{mg} / \mathrm{kg}$ of $\mathrm{Cd}$ in their roots. All urea level did not influence accumulated $\mathrm{Cd}$ in shoots of ramie grown without $\mathrm{Cd}$ as well as with $15 \mathrm{mg} \mathrm{kg}^{-1}$ of $\mathrm{CdCl}_{2} . \mathrm{H}_{2} \mathrm{O}$ but it changed $\mathrm{Cd}$ concentration in ramie grown in soil with $10 \mathrm{mg} \mathrm{kg}^{-1}$ of $\mathrm{CdCl}_{2} \mathrm{H}_{2} \mathrm{O}$ (Table 2).

Table 2. Effect of $\mathrm{Cd}$ and urea addition on Cd concentration of aerial part of ramie

\begin{tabular}{cccc}
\hline $\begin{array}{c}\text { Dosis } \mathrm{CdCl}_{2} \\
\left(\mathrm{mg} \mathrm{kg}^{-1}\right)\end{array}$ & \multicolumn{3}{c}{ Dosis Urea $(\mathrm{x} \mathrm{5} \mathrm{g)}$} \\
\cline { 2 - 4 } 0 & $0,42 \mathrm{a}$ & $0,47 \mathrm{a}$ & 1,50 \\
\hline & $\mathrm{A}$ & $\mathrm{A}$ & $0,46 \mathrm{a}$ \\
10 & $2,04 \mathrm{~b}$ & $1,04 \mathrm{~b}$ & $\mathrm{~A}$ \\
& $\mathrm{~B}$ & $\mathrm{~A}$ & $2,25 \mathrm{~b}$ \\
15 & $2,54 \mathrm{c}$ & $2,08 \mathrm{c}$ & $\mathrm{B}$ \\
& $\mathrm{B}$ & $\mathrm{AB}$ & $1,82 \mathrm{~b}$ \\
& & & $\mathrm{~A}$ \\
\hline
\end{tabular}


The result of this study was different from another study which showed that $\mathrm{Cd}$ accumulation in parts of plant depends on $\mathrm{N}$ supply. Singh et al. (1988) explained that nitrogen fertilization up to $100 \mathrm{mg} \mathrm{N} \mathrm{kg}{ }^{-1}$ increased $\mathrm{Cd}$ uptake of lettuce (Lactuca sativa L.). However Cd accumulation in respons to $\mathrm{N}$ supply is strongly depend on plant varieties or species. N-efficient rice genotype, Zhenshan $97 \mathrm{~B}$, accumulated less $\mathrm{Cd}$ and showed higher $\mathrm{Cd}$ tolerance than $\mathrm{N}$ inefficient rice genotype, Milyang 46. There was consistency between nitrogen uptake capacity and Cd tolerance in rice plants ( $\mathrm{Du}$ et al., 2009). This experiment used local variety of ramie which normally grown without fertilizer. It seemed that ramie was not too responsive to high $\mathrm{N}$ fertilization.

\section{Nitrogen and Sulfur Concentration of Shoot}

The role of $\mathrm{N}$ and $\mathrm{S}$ in protection mechanism of Cd toxicity by PC-CdS deposition in vacuole was clearly explained (Cobbett, 2000). It is assumed that increased $\mathrm{Cd}$ in shoots would be followed by increased $\mathrm{N}$ and $\mathrm{S}$ uptake. However, result demonstrated that effect of $\mathrm{Cd}$ level on $\mathrm{N}$ concentration did not depend on $\mathrm{N}$ amendment (Table 3). This result might be related with newly induced enzymes dedicated to coordinate leaf nitrogen remobilization and root nitrogen storage as discussed by Chaffei et al. (2004) for tomato (Lycopersicon esculentum). But, in this experiment $\mathrm{N}$ concentration of roots was not analyzed. Only urea which significantly increased $\mathrm{N}$ concentration up to $20 \%$ and $46.2 \%$ following 5.0 and $7.5 \mathrm{~g}$ urea addition, respectively (Table 3 ).

Table 3. Effect of Cd and urea addition on $\mathrm{N}$ concentration in shoots of ramie

\begin{tabular}{|c|c|c|c|c|}
\hline \multirow{2}{*}{$\mathrm{CdCl}_{2} \cdot \mathrm{H}_{2} \mathrm{O}\left(\mathrm{mg} \mathrm{kg}^{-1}\right)$} & \multicolumn{4}{|c|}{ Urea (g per pot) } \\
\hline & Control & 5.0 & 7.5 & Average \\
\hline \multicolumn{5}{|c|}{------------------------g-------------------------- } \\
\hline Control & 1.63 & 1.99 & 2.16 & $1.93 \mathrm{a}$ \\
\hline 10 & 1.79 & 2.19 & 2.41 & $2.13 \mathrm{a}$ \\
\hline 15 & 1.83 & 2.13 & 2.20 & $2.05 \mathrm{a}$ \\
\hline Average & $1.75 \mathrm{a}$ & $2.10 \mathrm{~b}$ & $2.56 \mathrm{~b}$ & \\
\hline
\end{tabular}

Neither Cd nor urea influenced $S$ concentration in ramie shoots. In this pot experiment, $\mathrm{S}$ concentration in shoots was between 0,11-0,14\%. Regression analysis showed that $\mathrm{Cd}$ contribution on $\mathrm{S}$ concentration enhancement was only $1 \%$. This result did not support the role of $\mathrm{S}$ in the synthesis of sisteinrich PC which contain $\mathrm{S}$ as expalined by Vatamaniuk et al. (2000). Plant sulfur metabolism is affected by Cd exposure, mainly as a consequence of GSH consuming activities to form PC. Rapid de novo synthesis of PCs in roots and leaves requires an increased synthesis of the tripeptide glutathione (GSH), which in turn depends on increased sulfur assimilation (Heiss et al., 1999) and increases the plant demand for reduced sulfur compounds. Results provide evidence that the increase of ATPs, OASs, GDH and PEPc activities, observed exclusively in S- deficient Cd-treated plants, may be part of the defence mechanism based on the production of phytochelatins (Astoffi et al., 2004). It suggests that ramie might has other mechanisms to protect $\mathrm{Cd}$ toxicity when grow in Cd-contaminated soil, or in this experiment soil Cd level was not higher enough to induce $\mathrm{N}$ and $\mathrm{S}$ concentration enhancement in shoots which is an important characteristics of Cd-accumulation plant.

\section{CONCLUSION}

Growing ramie as $\mathrm{Cd}$-phytoremediation plant in relatively high level $\mathrm{Cd}$ soil increased $\mathrm{Cd}$ accumulation in shoots up to $7.15 \mathrm{mg} \mathrm{kg}^{-1}$ without any toxicity symptomps. Enhanced $\mathrm{Cd}$ concentration in shoots was not followed by significant increase of $\mathrm{N}$ and $\mathrm{S}$ concentration. 


\section{ACKNOWLEDGEMENT}

The authors are grateful to Seed Inspection and Certification Institute for Food and Horticultural Plant, Bandung, West Java for providing green house, and to Agricultural Environment Research Institute, Pati, Central Java for preparing ramie's transplants. Authors are thankful to Higher Education General Director for financial support in year of 2009-2010.

\section{REFERENCES}

Alloway, BJ. 1995a. The Origin of heavy metals in soils. Pp. 38-56 in Heavy Metals in Soils. (BJ. Alloway, Ed). Blackie Academic \& Professional, Glasgow.

Alloway, BJ. 1995b. Cadmium. Pp. 122-147 in Heavy Metals in Soils. (BJ. Alloway, Ed). Blackie Academic \& Professional, Glasgow

Bradl, H, B Kimb, CU Kramar and D Stiibenc. 2005. Interactions of heavy metals. Pp 29164 in Heavy Metals in the Environment . (HB. Bradl, Ed). Elsevier Ltd., Amsterdan

Astoffi, S, R Zuchi and C Passera. 2004. Role of sulphur availability on cadmium-induced changes of nitrogen and sulphur metabolism in maize (Zea mays L.) leaves. I Plant Physiol.161: 795-802.

Chaffei, C, A Pageau, A Suzuki, H Gouia, MH Ghorbel and C Masclaux-Daubresse. 2004. Cadmium toxicity induced changes in nitrogen management in Lycopersicon esculentum leading to a metabolic safeguard through an amino acid storage strategy. Plant Cell Physiol. 45:1681-1693.

Chien, SH, G Carmona, LL Prochnow and ER Austin. 2003. Cadmium availability from granulated and bulk-blended phosphatepotassium fertilizers. J. Environ. Qual. 32: 1911-1914.

Choudhry, TM, WJ Hayes, AG Khan and CS Khoo. 1998. Phytoremediation-focusing on accumulator plants that remediate metalcontaminated soils.[online]. Australasian J. of $\quad$ Ecotoxic. 4:37-51. http://www.ecotox.org.au/aje/archives/vol4 p37.pdf (Diakses 11 Agustus 2011).

Cobbett, C.IS. 2000. Phytochelatins and their roles in heavy metal detoxification. Plant Physiol. 123: 825-832.
Du, Q MX Chen, R Zhou, ZW Chao, ZW Zhu., GS Shao and GM Guang. 2009. Cd toxicity and accumulation in rice plants vary with soil nitrogen status and their genotypic difference can be partly attributed to nitrogen uptake capacity. Rice Sc. 16:283291.

Eapen, S and SF D'Souza. 2005. Prospects of genetic engineering of plants for phytoremediation of toxic metals. Biotech. Adv. 23:97-114.

Farouk, S, AA Mosa, A Taha, HM Ibrahim and AM EL-Gahmery, A.M. 2011. Protective Effect of humic acid and chitosan on radish (Raphanus sativus, L. var. sativus) plants subjected to cadmium stress. J. of Stress Physiol. \& Biochem. 7: 99-116.

Gomes, PC, MPF Fontes, AG da Silva, SE Mendonça and AR Netto. 2001. Selectivity sequences and competitive adsorption of heavy metals by Brazilian soil. Soil Sc. Soc. Am. J. 65:1115-1121.

Heiss, S, HJ Schäfer, A Haag-Kerwer and T Rausch. 1999. Cloning sulfur assimilation genes of Brassica juncea L.: Cadmium differentially affects the expression of a putative low-affinity sulfate transporter and isoforms of ATP sulfurylase and APS reductase. Plant Mol Biol. 39:847-857.

Hindersah, R, DH Arief, S Soemitro and L Gunarto. 2007. Pengaruh inokulasi Azotobacter sp. LKM6 yang memproduksi eksopolisakarida dan aplikasi kadmium klorida terhadap kadmium di tanah dan tajuk selada. Pp 1140-1146 dalam Prosiding Kongres Himpunan Ilmu Tanah Indonesia (B Radjagukguk, BD. Kertonegoro, D. Shiddieq, BH. Sunarminto, SS. Wardoyo, M. Nurcholis, BH. Purwanto, NW. Yuwono dan Partoyo. Eds). UPN Veteran Yogyakarta Press. Yogyakarta.

Hindersah, R., Lusiani, L., Nurfatimah, M., Rosita, N., Ishamayana, S., Kamara, D.S. \& Soemitro, S.(2008). Induction of phytochelatin synthesis in lettuce leaf by cadmium that mobilized by Azotobacter sp. LKM6 bacteria. Pp. 300-305 in Proc. of The International Seminar on Chemisty (W Suratno, U Supratman, UMS Soedjanaatmadja, I Hastiawan, A Anggraeni, T Herlina and I Rahayu. Eds). Department of Chemistry Universitas Padjadjaran. Bandung 
Izadiyar, MH and B Yargholi. 2010. Study of cadmium absorption and accumulation in different parts of four forages. AmericanEurasian J. Agric. \& Environ. Sci. 9: 231238.

Jones, JB. Jr. 2001. Laboratory Guide for Conducting Soil Test and Plant Analysis. CRC Press. Boca Raton. 363 pp.

Mengel, K and EA Kirkby. 1987. Principles of Plant Nutrition. International Potash Institute. Bern. 849 pp.

Singh, JP, B Singh and SPS Karwasra. 1988. Yield and uptake response of lettuce to cadmium as influenced by nitrogen application. Nutr. Cycl. Agroecosyst. 18:49-56.

Vatamaniuk, OK, S Mari, YP Lu and PA Rea. 2000. Mechanism of heavy metal ion activation of phytochelin synthase. J. Biol. Chem. 275:31451-31459. 